\title{
Nematode parasites of the two limbless lizards: Turkish worm lizard, Blanus strauchi (Bedriaga, 1884) (Squamata: Amphisbaenidae), and slow worm, Anguis fragilis Linnaeus 1758 (Squamata: Anguidae), from Turkey
}

\author{
S. DÜȘEN ${ }^{1,4}$, İ. H. UĞURTAȘ², A. AYDOĞDU ${ }^{3}$
}

\begin{abstract}
${ }^{1}$ Pamukkale University, Faculty of Arts and Sciences, Department of Biology, Kinikli Campus, Kinikli, 20017 DenizliTURKEY, E-mail: sdusen@pamukkale.edu.tr, serdar2290@yahoo.com; ${ }^{2}$ Uludağ University, Faculty of Arts and Sciences, Department of Biology, Görükle Campus, 16059 Bursa-TURKEY; ${ }^{3}$ Uludağ University, Mustafakemalpaşa Vocational High School, Mustafakemalpaşa, Bursa-TURKEY
\end{abstract}

\begin{abstract}
Summary
In this investigation, seventeen Turkish worm lizards, Blanus strauchi, and eighteen slow worms, Anguis fragilis, collected from Turkey, were examined for helminths. Blanus strauchi harbored 2 species of Nematoda: Pharyngodon spinicauda and Aplectana sp. (larvae); Anguis fragilis harbored 5 species of Nematoda:, Rhabdias bufonis, Entomelas entomelas, Oswaldocruzia filiformis, Cosmocerca ornata and Oxysomatium brevicaudatum. Blanus strauchi represents a new host record for Pharyngodon spinicauda and Aplectana sp. Anguis fragilis, represents a new host record for Cosmocerca ornata. Turkey is a new locality record for Pharyngodon spinicauda.
\end{abstract}

Keywords: Anguis fragilis; Blanus strauchi; Nematoda; slow worm; Turkish worm lizard; Turkey

\section{Introduction}

The helminth parasites of two limbless lizards, Turkish worm lizard, Blanus strauchi, and slow worm, Anguis fragilis, were examined. Only nematodes observed, other helminths were also searched but not they observed in this study.

The Turkish worm lizard, B. strauchi, externally resembling an earthworm, it lives under the stones or in soil within sparsely vegetated bushy areas and is sometimes seen within or at the edges of woods. It feeds on insects. Blanus strauchi inhabits some Aegean islands, Turkey, Syria and Northern Iraq, with a vertical distribution to $1400 \mathrm{~m}$ (Baran and Atatür, 1998). The slow worm, A. fragilis, inhabits grassy meadows, woodlands, maquis (a scrubland vegetation of the Mediterranean region) and similiar richly vegetated areas with good ground cover and usually hides under stones or inside burrows in loose soil. It feeds on soft bodied invertebrates and insects. It is widely distributed in the majority of Europe and west Asia, with a vertical distribution to $2400 \mathrm{~m}$ (Baran and Atatür,
1998).

To our knowledge no helminthological reports have been published for B. strauchi; however one study of helminths for A. fragilis (Schad et al., 1960) in Turkey exists.

This is the first helminthological study for B. strauchi and second helminthological study for $A$. fragilis from Turkey.

\section{Materials and Methods}

B. strauchi were collected by hand between 1997 and 2007, from 5 localities in southern Turkey: Büyükçaltıcak, Antalya Province, $10 \mathrm{~m}$ elevation $\left(36^{\circ} 46^{\prime} \mathrm{N} ; 30^{\circ} 34^{\prime} \mathrm{E}\right)$, Hisarçandır, Antalya Province $1000 \mathrm{~m}$ elevation $\left(36^{\circ} 44^{\prime}\right.$ $\mathrm{N}$; $\left.30^{\circ} 26^{\prime} \mathrm{E}\right)$; Üzümlü-Fethiye, Muğla Province, $1000 \mathrm{~m}$ elevation $\left(36^{\circ} 48^{\prime} \mathrm{N}\right.$; $\left.29^{\circ} 11^{\prime} \mathrm{E}\right)$; Pamukkale University Campus, Denizli Province, $400 \mathrm{~m}$ elevation ( $37^{\circ} 44^{\prime} \mathrm{N} ; 29^{\circ}$ $\left.06^{\prime} \mathrm{E}\right)$ and Samandağ, Hatay province, $450 \mathrm{~m}$ elevation $\left(36^{\circ} 09^{\prime} \mathrm{N} ; 35^{\circ} 58^{\prime} \mathrm{E}\right)$. In total, 17 B. strauchi $(9$ males, 8 females) were examined for helminth parasites. The mean \pm SD snout-vent length (SVL) of specimens was $17.52 \pm$ $2.59 \mathrm{~cm}$, with a range from 11.0 to $20.5 \mathrm{~cm}$.

A. fragilis were collected by hand at 4 localities in northwestern Turkey, between 1998 and 2005: Altınoluk, Balıkesir Province, $200 \mathrm{~m}$ elevation $\left(39^{\circ} 48^{\prime} \mathrm{N} ; 27^{\circ} 12^{\prime} \mathrm{E}\right)$, Uludağ, Bursa Province 1200 m elevation $\left(40^{\circ} 06^{\prime} \mathrm{N} ; 2^{\circ}\right.$ 07' E), Akyazı, Sakarya Province, $200 \mathrm{~m}$ elevation (40 41' N; 30 38' E), Akçakoca, Düzce Province, $150 \mathrm{~m}$ elevation $\left(41^{\circ} 05^{\prime} \mathrm{N} ; 31^{\circ} 07^{\prime} \mathrm{E}\right)$. In total, $18 \mathrm{~A}$. fragilis ( 8 males, 7 females and 3 juveniles) were examined for helminth parasites. The mean \pm SD snout-vent length (SVL) of specimens was $24.03 \pm 6.26 \mathrm{~cm}$, with a range from 14.1 to $35.0 \mathrm{~cm}$.

The body cavity was opened by a longitidutinal ventral incision. The alimentary canal was excised and separated into stomach, small intestine, large intestine and rectum. The contents of each part and other organs (lungs, liver, gall bladder, kidneys) were each mixed with $0.5 \%$ saline 


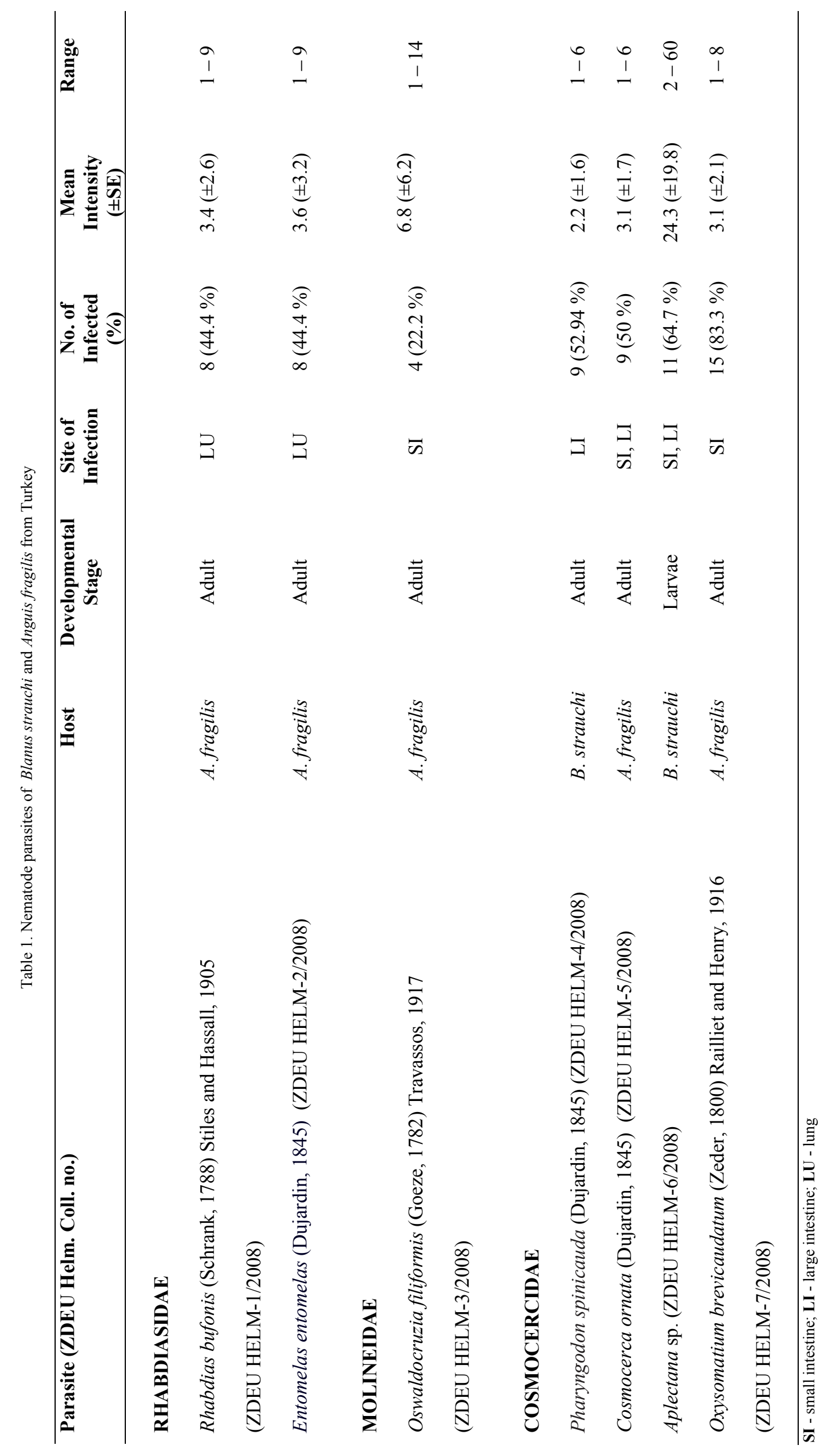


solution and poured into petri dishes for examination under a stereomicroscope. The muscles, plus portions of peritoneum and spinal cord, were teased out with needles and examined under a stereomicroscope. Nematodes were straightened by heat, fixed, and stored in $70 \%$ ethanol with $5 \%$ glycerol. Intensities are presented as mean values $( \pm \mathrm{SD})$ followed by the range. Voucher specimens of parasites were deposited in the Ege University, Museum of Zoology, Izmir, Turkey (ZDEU HELM 1-7/2008); host specimens were deposited in the Uludağ University, Department of Biology, Bursa Turkey.

\section{Results and Discussion}

In summary, 287 individuals of 2 helminth species were collected from 17 B. strauchi examined. Nematodes were observed in the large and small intestine, no helminths were observed in lungs of this species: 12 (70.6\%) individuals of $B$. strauchi examined harbored one or two nematode species in each individual the remaining 5 (29.4 $\%)$ were uninfected. There were $1.66 \pm 0.49$ helminth species per infected host.

Eighteen $A$. fragilis were examined, 162 individuals of 5 helminth species were collected. Nematodes were recorded the lungs, large and small intestine of this species. No individual host harbored more than 4 helminth species. Of the infected lizards, $2(11.1 \%)$ harbored 4 species of helminth, $6(33.3 \%)$ harbored 3 species of helminth, 7 (38.9 $\%$ ) harbored 2 species of helminth and 3 (16.7\%), harbored 1 species of helminth. There were $2.3 \pm 0.96$ helminth species per infected host and $9 \pm 7.32$ helminth individuals per infected host. Data on nematode infections of Blanus strauchi and Anguis fragilis are recorded in Table 1.

This is the first published study of helminths of B. strauchi from Turkey. B. strauchi represents a new host record for each of the collected parasite species (Pharyngodon spini- cauda and Aplectana sp.) in Turkey. Pharyngodon spinicauda was recorded various reptile and amphibian hosts in Europe (Lacerta, Ameiva, Ptychodactylus, Triton and Triturus) (Yamaguti, 1961). Four Aplectana species were reported from various amphibians in Turkey: Aplectana brumptii was recorded from Green toad (Bufo viridis) and Eastern spadefoot toad (Pelobates syriacus) by Schad et al. (1960) and Yildırımhan and Bursey (2010), similiarly Schad et al. (1960) reported Aplectana schneideri from Bufo regularis (probably Bufo viridis). Aplectana acuminata observed in Caucasian Salamander (Mertensiella caucasica), Luschan's Salamander (Lyciasalamandra billae) and common toad (Bufo bufo) (Yildirimhan et al., 2005b; Yıldırımhan and Öz, 2008; Yildırımhan and Karadeniz, 2007a). Aplectana macintoshii recorded in Bufo bufo (Y1ldırımhan and Karadeniz, 2007a). No reptile host records about Aplectana sp. in Turkey.

Schad et al. (1960) published an annotated list about some Turkish vertebrates. They recorded Entomelas entomelas, E. dujardini, Oswaldocruzia skrjabini and Oxysomatium brevicaudatum from Anguis fragilis in Turkey.

E. entomelas is a commonly observed nematode species for A. fragilis in Europe (Yamaguti, 1961). Baker (1980) redescribed the genus Entomelas specimens from $A$. fragilis and Ophisaurus apodus. He emended the generic diagnosis of Entomelas. E. dujardini is synonymized with E. entomelas. Schad et al. (1960) reported two species of Entomelas from A. fragilis (E. entomelas and E. dujardini), however, Baker (1980) accepted E. dujardini is synonym of E. entomelas, in this situation only E. entomelas distributing in Turkey.

The genera Paraentomelas, Hexadontophorus and $\mathrm{Ku}$ rilonema were synonymized with Entomelas. According to Anderson (2000), E. entomelas probably invaded snails and earthworms which serve as paratenic hosts, which could serve as the route of infection for A. fragilis in this study.

Table 2. The infection data comparison of $A$. fragilis

\begin{tabular}{|c|c|c|c|c|c|c|}
\hline Helminth Name & $\mathbf{N}$ & $\begin{array}{c}\text { Number of } \\
\text { infected } \\
\text { hosts }\end{array}$ & $\begin{array}{l}\text { Prevalence } \\
\text { (\%) }\end{array}$ & $\begin{array}{c}\text { Mean } \\
\text { intensity }\end{array}$ & Range & Reference \\
\hline \multirow[t]{4}{*}{ Entomelas entomelas } & 9 & 1 & 11.11 & - & - & Schad et al., 1960 \\
\hline & 2 & 1 & 50 & 3.00 & _ & Mihalca et al., 2007 \\
\hline & 19 & 1 & 5.26 & - & 1 & Shimalov et al., 2000 \\
\hline & 18 & 8 & 44.4 & 3.6 & $1-9$ & In this study \\
\hline \multirow[t]{3}{*}{ Oswaldocruzia filiformis } & 7 & 1 & 14.28 & - & $1-2$ & Borkovcová \& Kopřiva, 2005 \\
\hline & 19 & 2 & 10.52 & - & 1 & Shimalov et al., 2000 \\
\hline & 18 & 4 & 22.2 & 6.8 & $1-14$ & In this study \\
\hline \multirow[t]{2}{*}{ Cosmocerca ornata } & 19 & 1 & 5.26 & - & 1 & Shimalov et al., 2000 \\
\hline & 18 & 9 & 50 & 3.1 & $1-6$ & In this study \\
\hline \multirow[t]{4}{*}{ Oxysomatium brevicaudatum } & 9 & 1 & 11.11 & - & - & Schad et al., 1960 \\
\hline & 7 & 3 & 42.85 & - & $3-10$ & Mihalca et al., 2007 \\
\hline & 19 & 2 & 10.52 & - & $4-5$ & Shimalov et al., 2000 \\
\hline & 18 & 15 & 83 & 3.8 & $1-8$ & In this study \\
\hline
\end{tabular}


Table 3. Nematode species recorded in reptile species from Turkey

\begin{tabular}{|c|c|c|}
\hline Helminth Name & Host Species & Reference \\
\hline Entomelas entomelas (Dujardin, 1845) & Anguis fragilis & Schad et al., 1960, In this study \\
\hline Rhabdias bufonis (Schrank, 1788) Stiles and Hassall, 1905 & Anguis fragilis & In this study \\
\hline Rhabdias fuscovenosa (Railliet, 1899) Goodey, 1924 & $\begin{array}{l}\text { Natrix natrix } \\
\text { Natrix tesselata } \\
\text { Zamenis longissimus }\end{array}$ & $\begin{array}{l}\text { Yıldırımhan et al., } 2007 \mathrm{~b} \text {. } \\
\text { Yıldırımhan et al., } 2007 \mathrm{~b} \text {. } \\
\text { Düşen et al., } 2010\end{array}$ \\
\hline Strongyluris calotis Baylis and Daubney, 1923 & Laudakia stellio & Yildırımhan et al., 2006c. \\
\hline Oswaldocruzia filiformis (Goeze, 1782) Travassos, 1917 & Anguis fragilis & In this study \\
\hline Pharyngodon spinicauda (Dujardin, 1845) & Blanus strauchi & In this study \\
\hline Parapharyngodon kasauli (Chatterji, 1933) Markov and Bognadov, 1965 & Laudakia stellio & Yildırımhan et al., 2006c. \\
\hline Parapharyngodon tyche Sulahian and Schacher, 1968 & $\begin{array}{l}\text { Laudakia caucasica } \\
\text { Laudakia stellio }\end{array}$ & $\begin{array}{l}\text { Y1ldırımhan et al., 2006c. } \\
\text { Yildırımhan et al., 2006c. }\end{array}$ \\
\hline Thelandros taylori (Chatterji, 1935) Petter, 1966 & Laudakia stellio & Yildırımhan et al., 2006c. \\
\hline Thelandros baylisi (Chatterji, 1935) & Laudakia caucasica & Y1ldırımhan et al., 2006c \\
\hline Cosmocerca ornata (Dujardin, 1845) & Anguis fragilis & in this study \\
\hline Oxysomatium brevicaudatum (Zeder, 1800) Railliet and Henry, 1916 & $\begin{array}{l}\text { Anguis fragilis } \\
\text { Natrix natrix } \\
\text { Zamenis longissimus }\end{array}$ & $\begin{array}{l}\text { Schad et al., 1960, in this study } \\
\text { Schad et al., } 1960 . \\
\text { Düşen et al., } 2010\end{array}$ \\
\hline Eustrongylides excisus Jagerskiold, 1909 & $\begin{array}{l}\text { Natrix natrix } \\
\text { Natrix tessellata }\end{array}$ & $\begin{array}{l}\text { Y1ldirımhan et al., 2007b. } \\
\text { Yildırımhan et al., 2007b. }\end{array}$ \\
\hline Foleyella candezei (Fraipont, 1882) Seurat, 1917 & $\begin{array}{l}\text { Laudakia caucasica } \\
\text { Laudakia stellio }\end{array}$ & $\begin{array}{l}\text { Yildirımhan et al., 2006c. } \\
\text { Yildirımhan et al., 2006c. }\end{array}$ \\
\hline Aplectana sp. (larvae) & Blanus strauchi & in this study \\
\hline Kalicephalus sp. & $\begin{array}{l}\text { Coronella austriaca } \\
\text { Zamenis longissimus }\end{array}$ & $\begin{array}{l}\text { Düşen et al., } 2010 \\
\text { Düşen et al., } 2010\end{array}$ \\
\hline Ophidascaris sp. & Zamenis longissimus & Düşen et al., 2010 \\
\hline unidentified nematode cyst & Coronella austriaca & Düşen et al., 2010 \\
\hline unidentified cyst & Zamenis longissimus & Düşen et al., 2010 \\
\hline
\end{tabular}

Shimalov et al. (2000) recorded E. entomelas, Ox. brevicaudatum, O. filiformis and C. ornata in A. fragilis from Southern part of Belarus. Sharpilo (2003) reported distribution of $O x$. caucasicum in A. fragilis from Caucasus region. Borkovcová and Kopřiva (2005) observed, Ox. brevicaudatum, O. filiformis, R. fuscavenosus and Abbreviata sp. in A. fragilis, from South Moravia (Czech Republic). Mihalca et al. (2007) reported E. entomelas in $A$. fragilis from Romania. We observed (E. entomelas, $R$. bufonis, O. filiformis, Ox. brevicaudatum) in this study. The infection data comparison of $A$. fragilis between in this study and other related studies data given in Table 2 . A. fragilis represents a new host record for $C$. ornata, whereas the other nematode species $(O$. filiformis,
$O x$. brevicaudatum and $R$. bufonis) found in this investigation are common parasites of European anurans and reptiles (Yamaguthi, 1961; Buchvarov, 1977; Anderson, 2000), and these species have been observed in several amphibians and reptiles species in Turkey. Nematodes previously recorded in reptiles in Turkey, are given in Table 3. Future detailed studies are needed in Reptiles from Turkey to add other metazoan endoparasites to Turkish reptile helminthofauna.

\section{Acknowledgments}

We thank to the Department of National Parks and Wildlife of the Ministry of Forestry, of the Republic of Turkey 
for their helps. Authors indebted to the members of editorial board and referees of Helminthologia for constructrive comments on earlier versions of this manuscript.

\section{References}

ANDERSON R. C. (2000): Nematode Parasites of Vertebrates: Their Development and Transmission (2nd Edition). CABI Publishing, Wallingford, Oxon, U.K. 650 pp. BARAN, I., ATATÜR, M. K. (1998): Turkish Herpetofauna. The Republic of Turkey, Ministry of Environment Publications, Ankara. 214 pp.

BAKER, M. R. (1980): Revision of Entomelas Travassos, 1930 (Nematoda: Rhabdiasidae) with a review of genera in the family. Syst. Parasitol., 1 (2): 83 - 90

BORKOVCOVÁ, M., J. KOPŘIVA. (2005): Parasitic helminths of reptiles (Reptilia) South Moravia (Czech Republic). Parasitol. Res., 96: $77-78$

Buchvarov, G. K. (1977): Catalogue des Helminthes des Amphibies en Bulgarie, Universite de Plovdiv „P Hilendarski,“ Plovdiv, Bulgaria. 53 pp. (In Bulgarian)

DüşEN S., Öz, M. (2004): Helminth parasites of the tree frog, Hyla arborea (Linnaeus, 1758) (Anura: Hylidae) from Southwest Turkey. Comp. Parasitol., 71 (2): 258 261

DÜŞEN S., Öz, M. (2006): Parasitic helminths of the marsh frog, Rana ridibunda Pallas, 1771 (Anura: Ranidae), from Antalya Province, south-west Turkey. Comp. Parasitol., 73 (1): $121-129$

DÜŞEN, S. (2007): Helminths of the two mountain frogs, Banded frog, Rana camerani Boulenger, 1886 and Uludağ Frog Rana macrocnemis Boulenger, 1885 (Anura: Ranidae), collected from Antalya Province. Acta Parasitol. Tur., 31 (1): 84 - 88

DüŞEN, S., UĞURTAŞ, İ. H., Altunel F. N. (2010): Nematode Parasites of The Smooth Snake, Coronella austriaca Laurenti, 1768 and The Aesculapian Snake, Zamenis longissimus (Laurenti, 1768) (Ophidia: Colubridae), Collected from Northwestern Turkey. North-West J. Zool., 6 (1): $86-89$

Mihalca, A. D., C. Gherman, I. Ghira, Cozma, V. (2007): Helminth parasites of reptiles (Reptilia) in Romania. Parasitol. Res., 95: $77-78$

SAĞLAM, N., ARIKAN, H. (2006): Endohelminth parasites of the Marsh Frog Rana ridibunda from Hazar Lake, Turkey. Dis. Aquat. Org., 73: 253-260

Schad, G. A., KunTZ, R. E., Wells, W. H. (1960): Nematode parasites from Turkish vertebrates: an annotated list. Can. J. Zool., 38: 949 - 963

SHARPILO V. P. (2003): Rare and Locally Distributed Palearctic Species of the Reptile Parasitic Worms: Oxysomatium caucasicum (Nematoda, Cosmocertidae). Vestnik Zool., 37 (5): $69-72$

Shimalov, V. V., Shimalov, V. T., Shimalov, A. V. (2000): Helminth fauna of lizards in the Southern Part of Belarus. Parasitol Res., 86: 343

Yamaguti, S. (1961): Systema Helminthum. The nematodes of vertebrates. Vol. III, Part II. Intersciences Pub- lishers, London, England. United Kingdom. pp. 82 - 100. Yildirimhan, H. S., UĞURTaş, İ. H., Altunel, F. N. (1996): An investigation on helminths of Rana ridibunda Pallas, 1771 (marsh frog)

. Acta Parasitol. Tur., 20: 113 - 130 (in Turkish, with English abstract)

Yildirimhan, H. S., UĞURTAŞ, İ. H. Altunel, F. N. (1997a): An investigation on parasitic helminths of Rana macrocnemis Boulenger, 1885 (Uludag frog). Tr. J. of Zool., 21: $467-473$

Yildirimhan, H. S., OĞUZ, M. C., UĞURTAŞ, İ. H. (1997b): An investigation on the nematodes of some tailless frogs (Rana ridibunda, Bufo bufo and Pelobates syriacus) collected from the Bursa regions. Hacettepe Fen ve Müh. Bil. Derg., 18: 45 - 58 (in Turkish with English abstract)

YILDIRIMHAN, H. S. (1999): Researches on parasitic helminths of Bufo viridis Laurenti, 1768 (Anura: Amphibia). Tr. J. of Zool, 23: 177 - 195 (in Turkish with English abstract)

Yildirimhan, H. S., AYdoĞdu, A., UĞURTAŞ, I. H., Altunel, F. N. (2001): Helminth fauna of Bombina bombina (Linnaeus, 1767) (Fire-Bellied Toad) collected from Sakarya and Edirne (Turkey). Acta Parasitol. Tur., 25 (3): 308 - 311 (in Turkish, with English abstract)

Yildirimhan, H. S., KaradENIZ, E., GÜRKAN, E., KoYUn, M. (2005a): Metazoon parasites of the Marsh frog (Rana ridibunda Pallas, 1771; Anura) collected from the different regions in Turkey. Acta Parasitol. Tur., 29 (2): 135 - 139 (in Turkish, with English abstract)

Yildirimhan, H. S., Bursey C. R., GoldberG, S. R. (2005b): Helminth parasites of the Caucasian salamander, Mertensiella caucasica, from Turkey. Comp. Parasitol., 72 (1): $75-87$

Yildirimhan, H. S., Bursey C. R., GoldBerG, S. R., Öz, M. (2005c): Mertensiella luschani (Luschan' Salamander) Endoparasites. Herpetol. Rev., 36 (2): 161

Yildirimhan, H. S., GoldberG, S. R. Bursey, C. R. (2006a): Helminth parasites of the Banded Frog, Rana camerani (Ranidae) from Turkey. Comp. Parasitol., 73 (2): $222-236$

Yildirimhan, H. S., Bursey, C. R. GoldberG S. R. (2006b): Helminth parasites of the Taurus frog, Rana holtzi, and the Uludag frog, Rana macrocnemis, with remarks on the helminth community of Turkish anurans. Comp. Parasitol., 73 (2): $237-248$

Yildirimhan, H. S., GoldberG, S. R. Bursey, C. R. (2006c): Helminth Parasites of the Caucasian Agama, Laudakia caucasia, and the Roughtail Rock Agama, Laudakia stellio (Squamata: Agamidae), from Turkey. Comp. Parasitol., 73(2): $257-262$

Yildirimhan, H. S., Altunel, F. C., UĞUrtaş. İ. H. (2006d): Helminth Parasites of Hyla arborea (Linneaus, 1758) (Tree Frog) Collected from Bursa, Edirne and Sakarya. Acta Parasitol. Tur, 30 (1): 56 - 59 (In Turkish, with English abstract)

Yildirimhan, H. S., Karadeniz, E. (2007a): Helminth Parasites of the Common Toad, Bufo bufo (Linnaeus, 1758) (Anura: Bufonidae) from Northeast Turkey. Comp. 
Parasitol., 74 (1): $176-178$

Yildirimhan, H. S., Bursey, C. R., GoldBerG, S. R. (2007b): Helminth parasites of the Grass Snake, Natrix natrix, and the Dice Snake, Natrix tessellata (Serpentes: Colubridae), from Turkey. Comp. Parasitol. 74(2): $343-$ 354

YILDIRIMHAN, H. S., Öz M. (2008): Helminth Fauna of
Lyciasalamandra billae (Franzen \& Klewen) (Luschan Salamander) Collected from Antalya. Acta Parasitol. Tur. 32 (4): $390-392$

YILDIRIMHAN, H. S., BURSEY, C. (2010): Helminth parasites of the eastern spadefoot toad, Pelobates syriacus (Pelobatidae), from Turkey. Turk J Zool. 34: 311-319 (doi:10.3906/zoo-0810-2) 